\title{
Effect of Organic Compost Tea and Humic Acid to Reduce Dose of NPK Fertigation of Banana Plants cv."Grand Nain"
}

\author{
Nehad M. A. Abdel Gawad \\ Tropical Fruit Research Department, Horticulture Research \\ Institute, Agricultural Research Centre, Cairo, Egypt.
}

\begin{abstract}
7 HIS EXPERIMENT was carried out during two successive crop cycles of 2013/2014 (first ratoon plant) and 2014/2015 (second ratoon plant) of Giant Cavendishi banana (Musa spp. AAA sub group) cv. Grand Nain, grown in sandy soil. The goal of this research is to study beneficial effect of compost tea (compost extract), which abstracted by $1.0 \mathrm{~kg} / 10 \mathrm{~L}$ water or $2.0 \mathrm{~kg} / 10 \mathrm{~L}$ water and humic acid ( $2.5 \mathrm{~g} / \mathrm{L}$ water or $5 \mathrm{~g} / \mathrm{L}$ water) single or incombination to reduce the doses of chemical fertigiation by $20 \%$ of the recommended rate NPK(N:640 , P2O5: 80 ,K2O: 800 g/plant/year)in nine equal doses and added at monthly from March to Nov. on the growth, yield and fruit quality of Grand Nain banana. The dose of both treatments(compost tea) was 9 liter/hole for each date and humic acid was 3liter /hole for each date, compared to standard treatment NPK fertigation $100 \%$ of the recommended rate $(\mathrm{N}: 800, \mathrm{P} 2 \mathrm{O} 5: 100, \mathrm{~K} 2 \mathrm{O}$ : $800 \mathrm{~g} / \mathrm{plant} / \mathrm{year}$ ) as a control.
\end{abstract}

The results revealed that the plants receiving $80 \%$ NPK of the recommended rate plus compost tea $(2.0 \mathrm{~kg} / 10 \mathrm{~L}$ water or $1.0 \mathrm{~kg} / 10 \mathrm{~L}$ water) andthe combination with humic acid $(2.5 \mathrm{~g} / \mathrm{L}$ water or $5.0 \mathrm{~g} / \mathrm{L}$ water) treatments showed an increases in the vegetative growth parameters (psedostem height, circumference and assimilation area compared with the standard treatment of NPK fertigation (100\%). The highest values of yield and leaf contents of $\mathrm{N}$ and $\mathrm{K}$ were obtained from plants received (NPK fertigation $80 \%$ of the recommended rate pluscompost tea $2 \mathrm{~kg} / 10 \mathrm{~L}$ and humic acid $5 \mathrm{~g} / \mathrm{L}$ ) while, the lowest values were obtained with the plants received $80 \%$ NPK of the recommended rate only but had no significant effect on leaf $\mathrm{P}$ content. Organic compost tea $(2 \mathrm{~kg} / 10 \mathrm{~L} /$ water $)$ and humic acid $(5 \mathrm{~g} / \mathrm{L}$ water) was favorable for improving fruit quality in terms of increasing finger weight ( $119.00 \& 124.00 \mathrm{~g})$, total soluble solids \% (22.21\& $22.05 \%)$, total sugars (18.47 \& 18.16) compared with the other treatments. accordingto the obtained results, it can be concluded that using compost tea $(2 \mathrm{~kg} / 10 \mathrm{~L}$ water $)$ in combination with humic acid $(5 \mathrm{~g} / \mathrm{L}$ water ) reduce the recommended doses of the chemical fertilizers by $20 \%$.

Keywords: Organic compost tea, Humic acid, Grand Nain, Yield, Fruit quality. 
Banana is among the most important worldwide consumed fruit product (Musa spp.). It was reported that its word's production exceeded 91 million tonnes. Whereas it's total harvested area reached approximately (25073) ha. producing about (1129777) tons annually (FAO. 2012).Biological fertilization is based on the use of natural inputs including fertilizers, decaying remains of organicmatter, excess crops, domestic sewage, animal manure and microorganisms such as fungi and bacteria (Chirinos and Montilla, 2006).Bio fertilizations now are very important method for providing the plants with their nutritional requirements without having an undesirable impact on the environment (Abou El-Yaziedand Sellim, 2007). Bio fertilizers are known to improve fixation of nutrients in the rhizosphere, produce growth stimulants for plants, improve soil stability and provide biological control. They also biodegrade substances, recycle nutrients, promote mycorrhiza symbiosis and develop bioremediation processes in soils contaminated with toxic, xenobiotic and recalcitrant substances (Rivera-Cruz, et al., 2008). Compost, rich in plant nutrients, is a readily available fertilizer with beneficial effects on physical, chemical, biochemical and biological properties of the soils. Moreover compost-based treatments can exert protective effects against plant diseases occurrence and/or stimulate an enhanced plant physiological status with improvements in quantity and quality of crop productions (Loredana Liguori et al., 2015).

Compost tea in modern terminology means compost extract brewed with microbial food source, humic, fulvic acids and catalyst amendments to promote the growth and multiplication of microbes in the tea (Steve, 2009).Compost tea is a liquid extract produced by diluting compost with water. Anecdotal evidence suggests these teas may be effective against pathogens associated with foliar and fruit diseases. These organisms may work by inducing plant resistance, inhibiting pathogen growth, or outcompeting the pathogens. Some compost teas apparently contain large numbers of beneficial microbes that compete for space on leaves and fruits, denying pathogens space to colonize. Benefits described to the use of humic acid and related products to increase nutrient uptake, tolerance to drought and temperature extremes, activity of beneficial soil microorganisms, and availability of soil nutrients particularly in alkaline soils and low organic matter (Russo and Berlyn, 1990). Also, humic materials may increase root growth in a similar manner to auxins (Tatini et al., 1991).These water extractable components include active microorganisms, primarily bacteria, fungi and some protozoa, mineral nutrients, organic acids and other microbial by products.

Fertilization is an important and limiting factor for growth, productivity and production of banana plants because plants remove large amounts of nutrients from the soil. Among these nutrients, nitrogen is considered the prime nutrient for the plant growth. The sandy soils are considered recently, as the main area for agricultural extension, under such conditions, it is necessary to use the improved irrigation fertilization (fertigation) by adding the dissolved nutrients through a drip (trickle) irrigation system (Ibrahim, 2003). For growth and fruit

Egypt. J. Hort. Vol. 43, No. 2 (2016) 
production, bananas require high amounts of nutrients which are often supplied only in part by the soil. These nutrients have to be replaced in order to maintain soil fertility and to permit the continuous production of high yields. Hence the importance of nitrogen to bananas, it is considered second only in terms of the amount needed for growth and production. Nitrogen is strongly redistributed from old banana leaves to young ones. When banana plants grown in sand culture had access only to the nitrogen contained within the planting material, the effect on growth was more marked than with any other nutrient (Gowen, 1995). So, the major problems facing banana growers are the high costs of excessive manufactured fertilizers needs for banana plants. Several investigators reported that, combined application of Bio fertilizers and inorganic fertilizers increased soil N,P and K availability and decreased soil $\mathrm{pH}$ compared with the treatments with inorganic fertilizers alone of banana plants [Athani \& Hulamani (2000), ElShammaa, (2001), Suresh \& Hasan, (2001), Hammam et al. (2003), Abd ElMoniem \& Radwan, (2003), Gogoi et al. (2004), Damatto et al. (2007), Abd ElMoniem et al. (2008), Mohammed et al. (2010) and Barakat et al. (2011)].

\section{Materials and Methods}

This investigation was carried out during two successive experimental seasons at sandy soil at El-Khatataba region, Minofia Governorate Egypt. Plants from tissue culture were planted 3X3.5 m.apartin March 2012(mother plant). 2013 (first ratoon) and 2014 (second ratoon) of Grand Nain cultivar. The experimental soil in texture and deficient in fertility according to mechanical and chemical analysis (Table 1).

TABLE 1. Soil characteristics of the banana plantation at the start of the experiment.

\begin{tabular}{|l|c|c|c|}
\hline \multirow{2}{*}{ Properties } & \multicolumn{3}{|c|}{ Depth (cm) } \\
\cline { 2 - 4 } & $\mathbf{0 - 3 0}$ & $\mathbf{3 0 - 6 0}$ & $\mathbf{6 0 - 9 0}$ \\
\hline Coarse \% & 51.50 & 44.60 & 64.00 \\
\hline Fine sand \% & 23.0 & 28.40 & 22.00 \\
\hline Silt \% & 15.25 & 16.50 & 11.00 \\
\hline Clay \% & 13.25 & 10.50 & 3.00 \\
\hline Texture & Loamy sand & Sandy & Sandy \\
\hline Black density gm/cm & 1.56 & 1.64 & 1.70 \\
\hline pH & 5.0 & 8.2 & 8.40 \\
\hline E.C.m.mhos/cm & 0.53 & 0.61 & 0.70 \\
\hline $\mathrm{CaCO}$ & 0.72 & 0.81 & 0.78 \\
\hline $\mathrm{Na} \mathrm{meg/L}$ & 1.79 & 1.84 & 2.21 \\
\hline $\mathrm{K} \mathrm{meg/L}$ & 0.015 & 0.17 & 0.17 \\
\hline $\mathrm{Ca} \mathrm{meg/L}$ & 2.20 & 1.44 & 1.92 \\
\hline $\mathrm{Mg} \mathrm{meg} / \mathrm{L}$ & 0.84 & 0.74 & 0.54 \\
\hline $\mathrm{H} \mathrm{CO}_{3}$ & 2.16 & 2.44 & 2.93 \\
\hline $\mathrm{Cl} \mathrm{meg}_{\mathrm{yyy}}$ & 1.74 & 1.50 & 1.59 \\
\hline $\mathrm{SO}_{4} \mathrm{meg} / \mathrm{L}$ & 0.82 & 0.89 & 0.74 \\
\hline
\end{tabular}


All orchard plants received the recommended regular organic fertilization the farm compost was added to the soil at the first week of December $(60 \mathrm{~m} 3 / \mathrm{fed} /$ year). The source of water supply was well. The drip irrigation system with two lines per single row and promising micro-flapper emitters discharging 4 littre/ hour was used. The chemical fertilizers doses were added from Feb. until Nov. through drip irrigation system (fertigation).Ammonium nitrate (NH4NO3, $33.5 \% \mathrm{~N}$ ) was used as a source of nitrogen, phosphoric acid (45\% P2O5) was used as a source of phosphors and potassium sulphate $(50 \% \mathrm{~K} 2 \mathrm{O})$ was used as a source of potassium. Standard treatment, NPK fertilization $100 \%$ of the recommended rate NPK $(800,100,1000 \mathrm{~g} / \mathrm{plant})($ Ibrahim, 2003) and treatment, NPK fertilization $80 \%$ of the recommended rate $(640,80,800 \mathrm{~g} / \mathrm{plant})$, All the considered $\mathrm{N}, \mathrm{K}$ rates were divided into 20 doses/month while, $\mathrm{P}$ rate was divided into (8 doses / month) Table 2.

TABLE 2. Time and actual amount of NPK fertigated all year round to the experimental Grand Nain plants.

\begin{tabular}{|l|c|c|c|c|c|c|}
\hline \multirow{2}{*}{ Treatment } & \multicolumn{3}{|c|}{$\begin{array}{c}\text { Standard treatment } \\
\mathbf{1 0 0 \%} \text { NPK) }\end{array}$} & \multicolumn{2}{c|}{$\begin{array}{c}\text { Treatments (reduced of 20\% of } \\
\text { the recommended rate) }\end{array}$} \\
\cline { 2 - 7 } & $\begin{array}{c}\mathbf{N} \\
\text { g/plant }\end{array}$ & $\begin{array}{c}\mathbf{P}_{\mathbf{2}} \mathbf{O}_{\mathbf{5}} \\
\text { g/Plant }\end{array}$ & $\begin{array}{c}\mathbf{K}_{\mathbf{2}} \mathbf{O} \\
\text { g/plant }\end{array}$ & $\begin{array}{c}\mathbf{N} \\
\text { g/plant }\end{array}$ & $\begin{array}{c}\mathbf{P}_{\mathbf{2}} \mathbf{O}_{\mathbf{5}} \\
\text { g/Plant }\end{array}$ & $\begin{array}{c}\mathbf{K}_{\mathbf{2}} \mathbf{O} \\
\text { g/plant }\end{array}$ \\
\hline Feb. & 30 & 6 & 25 & 24 & 4.80 & 20 \\
\hline March & 45 & 8 & 60 & 36 & 6.40 & 48 \\
\hline April & 60 & 10 & 80 & 48 & 8.00 & 64 \\
\hline May. & 80 & 12 & 125 & 64 & 9.60 & 100 \\
\hline June & 100 & 12 & 145 & 80 & 9.60 & 116 \\
\hline July & 130 & 12 & 150 & 104 & 9.60 & 120 \\
\hline August & 140 & 12 & 175 & 112 & 9.60 & 140 \\
\hline Sept. & 100 & 12 & 130 & 80 & 9.60 & 104 \\
\hline Oct. & 80 & 10 & 70 & 64 & 8.00 & 56 \\
\hline Nov. & 35 & 6 & 40 & 28 & 4.80 & 32 \\
\hline Dec. & - & - & - & - & - & - \\
\hline Jan. & - & - & - & - & - & - \\
\hline Total & 800 & 100 & 1000 & 640 & 80 & 800 \\
\hline
\end{tabular}

- $\mathrm{N}$ and $\mathrm{K}$ were dissolved and applied through the trickle system in 20 doses /month.

- P was dissolved and applied through the trickle system in 8 doses /month.

- The annual rates per plant were 800 or $640 \mathrm{~g} \mathrm{~N} /$ plant in the form $60 \mathrm{NH}_{4} \mathrm{NH}_{3}, 100$ or $80 \mathrm{~g} \mathrm{P}_{2} \mathrm{O}_{5}$ /plant as $\mathrm{H}_{3} \mathrm{PO}_{3}$ and 1000 or $800 \mathrm{~g} \mathrm{~K}_{2} \mathrm{O}$ /plant as $\mathrm{K}_{2} \mathrm{SO}_{4}$.

\section{Compost tea preparation}

Compost tea (compost extract) was extracted by soaking $10 \mathrm{~kg}$ or $20 \mathrm{~kg}$ mature compost with 100 liter water $+100 \mathrm{~cm}$ Molasses for 7 days in a special unit, attached to air pump and the aerator provides continuous flow of air bubblers to extract compost tea until completion of the fermentation process and extract color becomes light Brown (Fayek et al. 2014). The microbial population and the chemical properties of compost tea is shown in (Table 3 a and b) compost tea was added as soil application in March to Nov. The dose of both treatments (compost tea) was 9 liter/mat for each date and humic acid was 3liter /mat for each date.

Egypt. J. Hort. Vol. 43, No. 2 (2016) 
TABLE (3-a). Microbial population of organic compost tea

\begin{tabular}{|l|c|}
\hline Bacterial Plate count $(\mathrm{CFU} / \mathrm{ml})$ & $7.1 \times 107$ \\
\hline Bacterial Direct count $(\mathrm{cell} / \mathrm{ml})$ & $6.4 \times 108$ \\
\hline Spore forming bacteria $(\mathrm{CFU} / \mathrm{ml})$ & $7 \times 104$ \\
\hline Total fungi $(\mathrm{CFU} / \mathrm{ml})$ & $1.1 \times 104$ \\
\hline Actinomycetes $(\mathrm{CFU} / \mathrm{ml})$ & $2.8 \times 105$ \\
\hline
\end{tabular}

$(\mathrm{CFU})=$ Colony Forming Unit

TABLE (3-b). Chemical analysis of the organic compost tea

\begin{tabular}{|l|c|}
\hline Parameter & Compost tea (extract) Composition \\
\hline Cubic meter weight & $530 \mathrm{~kg}$ \\
\hline Moisture $\%$ & $33.6 \%$ \\
\hline Organic matter\% & $45 \%$ \\
\hline $\mathrm{pH}(1: 10)$ & 7.44 \\
\hline $\mathrm{EC}(\mathrm{ds} / \mathrm{m})$ & 2.33 \\
\hline C/N ratio & 22.2 \\
\hline Total N\% & $1.15 \%$ \\
\hline Total $\mathrm{P} \%$ & $0.92 \%$ \\
\hline Total $\mathrm{K} \%$ & $1.25 \%$ \\
\hline Total $\mathrm{Ca} \%$ & $1.95 \%$ \\
\hline Total $\mathrm{Mg} \%$ & $0.85 \%$ \\
\hline Total $\mathrm{Fe}(\mathrm{ppm})$ & $1960 \mathrm{ppm}$ \\
\hline Total $\mathrm{Mn}(\mathrm{ppm})$ & $450 \mathrm{ppm}$ \\
\hline Total $\mathrm{Zn}(\mathrm{ppm})$ & $140 \mathrm{ppm}$ \\
\hline Total $\mathrm{Cu}(\mathrm{ppm})$ & $28 \mathrm{ppm}$ \\
\hline
\end{tabular}

Treatments:

- T1: Standard treatment NPK fertigation $(100 \%$ of the recommended rate $800+100+1000$ g/plant/year)

- T2: NPK fertigation ( $80 \%$ NPK of the recommended rate: $640+80+800 \mathrm{~g} / \mathrm{plant} / \mathrm{year}$ )

- T3: NPK fertigation $80 \%$ NPK of the recommended rate + compost tea $1 \mathrm{~kg} / 10 \mathrm{~L}$.water

- T4: NPK fertigation $80 \%$ NPK of the recommended rate + compost tea $2 \mathrm{~kg} / 10 \mathrm{~L}$. water

- T5 :NPK fertigation $80 \%$ of the recommended rate + humic acid $2.5 \mathrm{~g} / \mathrm{L}$. water

- T6: NPK fertigation $80 \%$ of the recommended rate + humic acid $5 \mathrm{~g} / \mathrm{L}$. water

- T7: NPK fertigation $80 \%$ of the recommended rate + compost tea $1 \mathrm{~kg} / 10 \mathrm{~L}$. water +humic acid $2.5 \mathrm{~g} / \mathrm{L}$. water.

- T8: NPK fertigation $80 \%$ of the recommended rate + compost tea $1 \mathrm{~kg} / 10 \mathrm{~L}$. water +humic acid $5 \mathrm{~g} / \mathrm{L}$. water.

- T9: NPK fertigation $80 \%$ of the recommended rate + compost tea $2 \mathrm{~kg} / 10 \mathrm{~L}$. water +humic acid $2.5 \mathrm{~g} / \mathrm{L}$. water.

- T10: NPK fertigation $80 \%$ of the recommended rate + compost tea $2 \mathrm{~kg} / 10 \mathrm{~L}$. water + humic acid $5 \mathrm{~g} / \mathrm{L}$. water. 
The following parameters were used to evaluate the tested treatments: Vegetative growth

Morphological measurements were done at bunch shooting stage via the following parameters: pseudostem height $(\mathrm{cm}$.$) , pseudostem circumference$ (cm.), number of green leaves per plant, leaf area $(\mathrm{m} 2 / \mathrm{leaf})$ and assimilation area per plant (m2/plant).Assimilation area was determined using the equation $=$ leaf area X number of green leaves (Ibrahim, 1993).

\section{Bunch characteristics}

At time of harvesting, bunch weight $(\mathrm{kg})$, number of hand/bunch and number of finger /hand were counted and recorded.

Finger parameters (physical and chemical) properties of fruits:

Finger weigh $(\mathrm{g})$, finger length and diameter $(\mathrm{cm})$, were estimated from samples of mature fruits taken from the middle portion of each two hands of bunch. Total sugar and titratable acidity were determined according to A.O.A.C (2000) T.S.S were estimated by hand refractometer.

Yieldwas calculated according to the following equations:

Yield $=$ Bunch weight $(\mathrm{kg}) \mathrm{X}$ Number of plant $/$ fed

Leaf mineral content of $N, P$ and $K$ were also determined as follow:

Samples of leaves were taken from the third upper leaf in the descending foliar succession of the plant after bunch shooting as recommended by (Hewitt, 1955) and adopted by (Saad and Saad, 2007). Total nitrogen was determined by using micro-kjeldehl method as described by (Pregel, 1945). Phosphorus was determined according to the colorimetric method of Troug and Meyer (1939). Potassium was determined according to photometric method described by (Brown and Lilleland 1946).

\section{Statistical analysis}

The design of this experiment was randomized complete block design. Each treatment contained three replicates and each replicate had three hole with three plants in each hole. Data were tabulated and statistically analyzed according to Snedecor and Cochran (1980)and differences between various treatments mean were tested by New LSD according toWaller \&Duncan (1969).

\section{Vegetative growth}

\section{Results and Discussion}

Data presented in Table 4 indicated that vegetative growth parameters (pseudostemheight, pseudostem, circumference, number of leaves/plant, leaf area and assimilation area) of Grand Nain banana plants at bunch shooting stage were significantly affected by compost tea applications in the two seasons of the study. The best results with regard to pseud. height $(310.67 \& 305.00 \mathrm{~cm})$ pseud. circumference $(90.00 \& 88.33 \mathrm{~cm})$, number of leaves/plant $(14.67 \& 14.33$ leaf/plant), leaf area ( $2.36 \& 2.42 \mathrm{~m} 2 / \mathrm{leaf})$ and assimilation area (34.62 \& 34.67 $\mathrm{m} 2 /$ plant $)$ were obtained with the plants receiving $80 \%$ NPK $(640+80+800$ $\mathrm{g} /$ plant) plus organic fertilizers ( compost tea $2 \mathrm{~kg} / 10$ litter water + humic acid 5 $\mathrm{g} / \mathrm{L}$.) while, the lowest values to pseud. height ( $230.67 \& 226.33 \mathrm{~cm}$ ), pesud. Egypt. J. Hort. Vol. 43, No. 2 (2016) 
Circumference $(74.33 \& 69.33 \mathrm{~cm})$, number of leaves $(12 \& 12.33$ leaf/plant), leaf area $(1.38 \& 1.51 \mathrm{~m} 2 / \mathrm{leaf})$, assimilation area $(16.56 \& 18.61 \mathrm{~m} 2 / \mathrm{plant})$ were recorded with the treatment $(80 \%$ NPK fertigation and untreated compost tea or humic acid) in both tested seasons, respectively. These results are in agreement with those obtained by Abd El-Moniem \& Radwan (2003), Hammam, (2003), Hammam et al. (2003), Damatto et al. (2007), Thippesha et al. (2008)and Barakat et al. (2011) who found that the plants receiving 25 or $50 \%$ NPK plus bio-fertilizersshowed slight increases in the vegetative growth parameters.

\section{Bunch weight and yield}

Data presented in Table 5 indicated that bunch weight (kg/plant) and yield (ton/fed.) were significantly of affected by different organic fertilizers treatments during the studied seasons. Plants fertilized using $80 \%$ NPK of the recommended rate $(640,80,800 \mathrm{~g} /$ plant $)$ plus compost tea $2 \mathrm{~kg} / 10 \mathrm{~L}$. and humic acid $5 \mathrm{~g} / \mathrm{L}$. was greatly increased bunch weight $(32.41 \& 31.37 \mathrm{~kg} / \mathrm{plant})$ and yield ( 35.65\&33.50ton/fed) followed by T9, T8, T7,T1 ( standard treatment), T4, T3, T6, T5 ascending order. While the lowest were obtained from plants received the $80 \%$ NPK of the recommended rate + untreated compost tea or humicacid (19.35 \& $18.36 \mathrm{~kg} / \mathrm{plant}$ and $21.28 \& 19.19$ ton /fed) in both tested seasons. These results are in agreements with those reported by Athani \& Hulamani (2000), Suresh \& Hasan (2001), Abd El- Moniem \& Radwan (2003), Hammam (2003), Hammam et al. (2003), Gogoi et al. (2004), Damatto et al. (2007) and Thippesha et al. (2008) who report that the yield significantly increased as a result of receiving $75 \%$ NPK plus biofertilizers compared with the other treatments. Moreover, the biofertilizer improve plant physiological processes i.e. increased cell divisions, enlargement and consequently increased vegetative growth which positively reflected on the yield and yield components (El-Kafrawy, 2005). Also, Kamel (2002) demonstrated that fertilizing banana plants with farm refuse compost at $75 \mathrm{~kg} /$ hole improved effectively bunch weight. In additions, Abd ElNaby \& El-Sonbaty (2005) recorded that banana plants supplied with mineral fertilizers combined with organic manure (farm refuse compost) at $25+75 \%$ improved bunch weight.

\section{Finger parameters}

Table 6 cleared that, hand number/bunch, fingers number/hand and fingers number/bunch were significantly affected by different organic treatments during the two studied seasons. Whatever, treating Grand Nain banana by compost tea treatment at $80 \%$ NPK fertigation of the recommended rate plus compost tea $20 \mathrm{~kg} / \mathrm{L}+$ humic acid $5 \mathrm{~g} / \mathrm{L}$ gave the highest values of hand number $(13.67 \&$ $13.00)$, fingers number/hand $(20.67 \& 19.67)$ and fingers number/bunch $(245.40$ $\&$ 233.80) comparing with the other treatments. These results are in accordance with those obtained by Abd El-Naby (2000), Suresh \& Hasan (2001), Abd ElMoniem \& Radwan (2003), Hammam (2003), Hammam et al. (2003), Gogoi et al. (2004), Damatto et al. (2007) and Thippesha et al. (2008) who found that the best fingers parameters were which was applied with banana compost application and with 50 or $25 \%$ chemical fertilizer. 


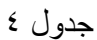

Egypt. J. Hort. Vol. 43, No. 2 (2016) 
TABLE 5. Effect of compost tea, humic acid and different levels of NPK on bunch weight and yield of Grand Nain banana plants during 2013 and 2014 seasons

\begin{tabular}{|c|c|c|c|c|}
\hline \multirow[t]{2}{*}{ Treatments } & \multicolumn{2}{|c|}{$\begin{array}{l}\text { bunch weight } \\
(\mathrm{kg})\end{array}$} & \multicolumn{2}{|c|}{ Yield/feddan } \\
\hline & 2013 & 2014 & 2013 & 2014 \\
\hline $\begin{array}{l}\text { T1:Standard treatment } \\
\text { NPK fertigation }(100 \% \text { of the recommended rate } \\
800+100+1000 \mathrm{~g} / \text { plant })\end{array}$ & 27.50 & 27.50 & 30.25 & 30.25 \\
\hline $\begin{array}{l}\text { T2: NPK fertigation ( } 80 \% \text { of the recommended } \\
\text { rate, } 640+80+800 \mathrm{~g} / \text { plant })\end{array}$ & 19.35 & 18.36 & 21.28 & 19.19 \\
\hline $\begin{array}{l}\text { T3: NPK fertigation } 80 \% \text { of the recommended rate } \\
\text { + compost tea } 1 \mathrm{~kg} / 10 \mathrm{~L} \text {. water. }\end{array}$ & 23.00 & 21.30 & 25.30 & 23.43 \\
\hline $\begin{array}{l}\text { T4: NPK fertigation } 80 \% \text { of the recommended rate } \\
\text { + compost tea } 2 \mathrm{~kg} / 10 \mathrm{~L} \text {. water. }\end{array}$ & 23.50 & 21.50 & 25.85 & 23.65 \\
\hline $\begin{array}{l}\text { T5 :NPK fertigation } 80 \% \text { of the recommended rate } \\
+ \text { humic acid } 2.5 \mathrm{~g} / \mathrm{L} \text {. water. }\end{array}$ & 20.33 & 21.17 & 22.36 & 23.28 \\
\hline $\begin{array}{l}\text { T6: NPK fertigation } 80 \% \text { of the recommended rate } \\
\text { + humic acid } 5 \mathrm{~g} / \mathrm{L} \text {. water. }\end{array}$ & 21.70 & 21.17 & 23.87 & 23.28 \\
\hline $\begin{array}{l}\text { T7: NPKfertigation } 80 \% \text { of the recommended rate } \\
\text { + compost tea } 1 \mathrm{~kg} / 10 \mathrm{~L} \text {. water +humic acid } 2.5 \mathrm{~g} \\
\text { /L. water. }\end{array}$ & 25.14 & 24.70 & 27.65 & 27.17 \\
\hline $\begin{array}{l}\text { T8: NPKfertigation } 80 \% \text { of the recommended rate } \\
+ \text { compost tea } 1 \mathrm{~kg} / 10 \mathrm{~L} \text {. water +humic acid } 5 \mathrm{~g} / \mathrm{L} \text {. } \\
\text { water. }\end{array}$ & 29.95 & 29.76 & 32.94 & 32.73 \\
\hline $\begin{array}{l}\text { T9: NPK fertigation } 80 \% \text { of the recommended rate } \\
+ \text { compost tea } 2 \mathrm{~kg} / 10 \mathrm{~L} \text {. water +humic acid } 2.5 \\
\text { g/L. water. }\end{array}$ & 31.88 & 30.11 & 33.06 & 33.12 \\
\hline $\begin{array}{l}\text { T10: NPKfertigation } 80 \% \text { of the recommended rate } \\
+ \text { compost tea } 2 \mathrm{~kg} / 10 \mathrm{~L} \text {. water +humic acid } 5 \mathrm{~g} \\
\text { /L. water. }\end{array}$ & 32.41 & 31.37 & 35.65 & 34.50 \\
\hline NewL.S.D at 0.05 level & 2.372 & 2.775 & 3.309 & 3.153 \\
\hline
\end{tabular}

Data presented in Table 6 indicated that finger weight, finger length and diameter were significantly affected by different doses of organic fertilization treatment during the two studied seasons. The highest values for finger weight $(119 \& 124 \mathrm{~g})$, finger length $(18.23 \& 18.05 \mathrm{~cm})$ and finger diameter $(3.86 \&$ $3.81 \mathrm{~cm}$ ) were obtained the plants receiving $80 \%$ NPK fertilizers of the recommended rate plus compost tea $20 \mathrm{~kg} / 100 \mathrm{~L}+$ humic acid $5 \mathrm{~g} / \mathrm{L}$ as compared with the other treatments. 
TABLE 6.

Egypt. J. Hort. Vol. 43, No. 2 (2016) 


\section{Fruit chemical parameters}

As shown in Table 7 fruit chemical parameters (TSS\%, total sugar) in banana fruit was significantly affected by different fertilization treatments during the two studied seasons. Acidity (\%) of banana fruit was insignificantly affected by compost tea treatments. The present results are in agreement with those obtained by Athani \& Hulamani (2000), Suresh \& Hasan (2001), Abd El- Moniem \& Radwan (2003), Hammam (2003), Hammam et al. (2003) and Thippesha et al. (2008) who found that organic fertilization by using compost tea was favorable for improving fruit quality.

\section{Leaf Mineral contents}

The effect of compost tea treatments and NPK fertigation on NPK leaf content of Grand Nain during two seasons are shown in Table 7. Leaf $\mathrm{N}$ and $\mathrm{K}$ contents were significantly affected by compost tea applications, the plant which received $80 \%$ NPK plus bio-fertilizers (compost tea $20 \mathrm{~kg} / 100 \mathrm{~L}$ + humic acid 5 $\mathrm{g} / \mathrm{L}$ ) gave the higher leaf minerals content $(\mathrm{N}$ and $\mathrm{K}$ ) followed by standard treatment NPK fertigation ( $100 \%$ of the recommended rate $800+100+800$ $\mathrm{g} /$ plant) compared as the other treatments. In addition, the results of leaf $\mathrm{P}$ content between treatmentswere insignificant. These results go in line with Mostafa et al. (2009) and Mohammed et al. (2010) who showed that application of compost tea gave the higher leaf N,P,K contents compared with control. According to the results obtained in this experiment, it can be concluded that using compost tea (NPK fertigation $80 \%$ of the recommended rate + compost tea $20 \mathrm{~kg} / 100 \mathrm{~L}+$ humic acid $5 \mathrm{~g} / \mathrm{L}$ ) led to reduction by $20 \%$ of recommended amount of fertilizers added. The plants receiving bio-fertilizers combination (humic acid and compost tea) gave better results of all vegetative growth and yield. 
TABLE 7.

Egypt. J. Hort. Vol. 43, No. 2 (2016) 
References

A.O.A.C. (2000) "Official Methods of Analysis" $17^{\text {th }}$ ed., Association of Official Analytical Chemistry, USD.

Abd El-Moniem, E.A., Abd-Allah, A.S.E. and Ahmed, M.A. (2008) The combined effect of some organic manures, mineral $\mathrm{N}$ fertilizers and algal cells extract on yield and fruit quality of Williams banana plants. Amer.-Eurasian J. Agric. \& Environ. Sci., 4 (4), 417-426, ISSN 1818-6769.

Abd El-Moniem, E.A.A. and Radwan, S.M.A. (2003) Response of Williams banana plants to biofertilization in relation to growth, productivity and fruit quality. Arab Univ. J. Agric. Sic. Ain Shams Univ., 11, 751-763.

Abd El-Naby, S.K.M. and El-Sonbaty, M.R. (2005) Effect of partial replacement of chemical fertilizers by organic manures in banana production and fruit quality. Assiut J. Agric. Sci., 36, 107-122.

Abd El-Naby, S.K.M. (2000) Effect of banana compost as organic manure on growth, nutrients status, yield and fruit quality of Maghrabi banana. Assiut J. Agric. Sci., 3, $101-114$.

Abou El-Yazied, A.M. and Sellim, A.S.M. (2007) Effect of reducing N, P mineral fertilization levels combined with Bio Fertilizer on growth, yield and tuber quality of potato plants. J. Agric. Sci., 32, 2701-2726.

Athani, S.I. and Hulamani, N.C. (2000) Effect of vermicompost on fruit yield and quality of banana cv. Rajapuri (Musa AAB). Karnataka J. Agri. Sci., 13 (4), 942-946

Barakat, M.R., El-Kosary, S. and Abd-Einafea, M.H. (2011) Enhancing Williams banana cropping by using some organic fertilization treatments. J. of Hort. Sci. \& Ornamental Plants, 3 (1), 29-37.

Brown, J.D. and Lilleland, O. (1946) Rapid determination of potassium and sodium in plant material and soil extract by flame photometry. Proc. Amer. Hort. Sci., 48, 341346.

Chirinos, J., Leal, A. and Montilla, J. (2006) Use alternative biological inputs for sustainable agriculture in the South of Anzoategui state. Applied and Interdisciplinary Sci., Biotechnology. Digital Magazine Ceniap Today, 11, 1-7.

Damatto-Junior, E.R., Boas, R.L.V. and Leonel, S. (2007) Influence of fertilization with organic compost in plant growth, development and production of banana 'Prataana' (Musa AAB).Energia-na-Agricultura. 22 (2), 27-37

El-Kafrawy, A.A.M. (2005) Physiolgical studies on banana plant. Ph.D. Thesis, Fac. Agric., Moshtohor, Zagazig Univ., Eygpt, 210p.

El-Shammaa, M.S. (2001) Effect of biofertilizers on growth and yield of banana plants (Williams cv.). Assiut J. Agri. Sci., 32 (1), 157-166.

FAO (2012) Food and Agriculture organization of the united nations rome. 
Fayek, M.A., Fayed, T.A., Fakhrani, E.M. and Shaymmaa, N.S. ( 2014) Yield and fruit quality of " Le-conte" pear trees as affected by compost tea and some antioxidants applications. J. Hort. Sci. Ornamental Plants, 6 (1), 01-08.

Gogoi, D., Kotoky, U. and Hazarika, S. (2004) Effect of biofertilizers on productivity and soil characteristics in banana. Indian J. Hort., 61 (4), 354-356

Gowen, S. (1995) "Banana and Plantains", Chapman \& Hall London, p.597.

Hammam, M.S. (2003) Effect of biofertilization on growth and fruiting of Cavendish and Williams banana. Egypt. J. Hort., 30 (1/2), 67-81.

Hammam, M.S.,Ibrahim, E.G. and Mansour, A.E.M. (2003) Response of Williams banana to some organic nitrogen fertilizers. Egypt J. Hort., 30, 51-65.

Hewitt, C.W. (1955) Leaf analysis as a guide to the nutrition of banana. Emp. J. Exp. Agric., 23, 11-16.

Ibrahim, E.G. (1993) Studies on irrigation of banana. Ph.D. Thesis, Fac. Agri. Zagazig Univ., Egypt.

Ibrahim, E.G. (2003) Productivity, water use and yield efficiency of banana under different irrigation system and water quantity in sandy soil. Egypt. J. Appl. Sci., 18 (10) 334-348.

Kamel, A.B. (2002) Physical studies on Biofertilization of Banana Plants cv. Williams . Ph.D. Thesis, Fac. Agric. Minia. Univ., Egypt, 127 p.

Loredana, L., Catello, P., Donatella, A., Giuseppe, C., Massimo, Z. and Marisa, D. (2015) Compost and compost tea management of mini watermelon cultivations affects the chemical, physical and sensory assessment of the fruits. Agri. Sci., 6, 117-125

Mohammed, S.M., Fayed, T.A., Esmail, A.F. and Abdou, N.A. (2010) Growth, nutrient status and yield of Le-Conte pear trees as influenced by some organic and bioferilizer rates compared with chemical fertilizer. Bull. Fac. Agric. Cairo Univ., 61, 17-32.

Mostafa, M.F.M., El-Boray, M.S.S., AbdElwahab, A.F. and Barakat, R.A. (2009) Effect of enriched compost tea on Washington navel orange trees. J. Agric. Sci. Mansoura Univ., Egypt, 34, 10085-10094.

Pregel, F. (1945) "Quantitative Organic Microanalysis", $4^{\text {th }}$ ed. J.A. Churchill. Ltd., London, $53 \mathrm{p}$.

Rivera-Cruz, M.D.C, Trujillo, N.A., Cordova, B.G., Kohler, J., Caravaca, F. and Roldan, A. (2008) Poultry manure and banana waste are effective biofertilizer carriers for promoting plant growth and soil sustainability in banana crops. SoilBiology-and-Biochemistry, 40 (12), 3092-3095

Russo, R.O. and Berlyn, G.P. (1990) The use of organic biostimulants to help low input sustainable agriculture. J. Sus. Agric., 1 (2), 9 - 42.

Egypt. J. Hort. Vol. 43, No. 2 (2016) 
Saad, I.R. and Saad, M.M. (2007) Effect of different organic nitrogen sources on growth yield and fruit quality of Williams banana. J. Adv. Agric. Res., 12 (1), 149-164.

Snedecor, G.W. and Cochran, W.G. (1980) "Statistical Methods" $7^{\text {th }}$ ed. The lowa State Univ. Press. Amer., lowa, U.S.A.

Steve, D. (2009) Sustainable farming compost tea. Cited in http://www.soil soup.com.

Suresh, C.P. and Hasan, M.A. (2001) Studies on the response of Dwarf Cavendish banana (Musa AAA) to biofertilizer inoculation. Hort. J., 14 (1), 35-41

Tatini, M., Bertoni, P., Landi, A. and Traversi, M.L. (1991) Effect of humic acids on growth and biomass portioning of container-grown olive plants. Acta Hort., 294, 75- 80 .

Thippesha, D., Srinivas, V., Mahanthesh, B. and Janardhan, G. (2008) Effect of different levels of nutrition and spacing on post harvest qualities of banana cv. Robusta (AAA) under high density planting systems, Asian J. Hort., 3 (1), 87-89.

Troug, E. and Meyer, A.H. (1939) Improvement in deiness colorimetric method for phosphorous and arsenic. Ind. Eng. Chem. Anal. Ed., 1, 136-139.

Waller, R.A. and Duncan, D.B. (1969) A buyes rule for the symmetric multiple comparison problem. Amer. State. Assoc. J., 64, 1484-1503.

(Received 6/7/2016, accepted 3/10/2016) 


$$
\begin{aligned}
& \text { تأثير مستخلص الكمبوست العضوى و حمض الهيوميك لتقليل }
\end{aligned}
$$

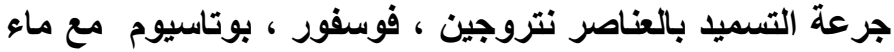

$$
\begin{aligned}
& \text { الرى فى نباتات الموز صنف "جراندنان" نتروجن } \\
& \text { نهاد مصطفى أحمد عبد الجواد } \\
& \text { قسم بحوث الفاكهة الأستو ائية ـ معهد بحوث البساتين - مركز البحوث الزراعية ـ }
\end{aligned}
$$

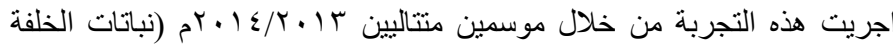

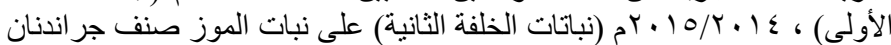

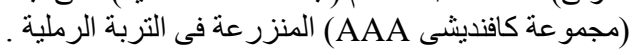

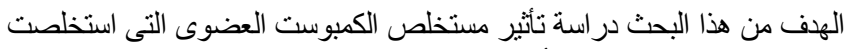

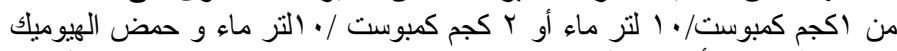

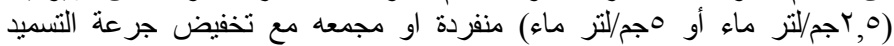

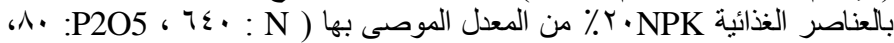
K2O

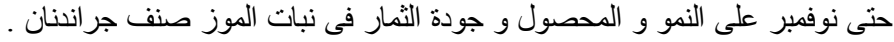

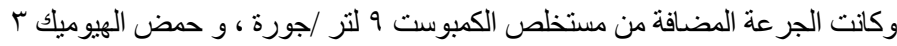

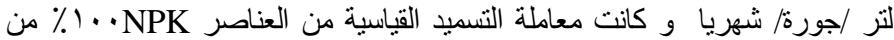

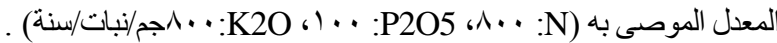

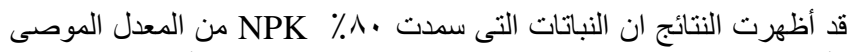

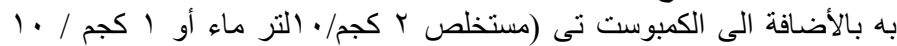

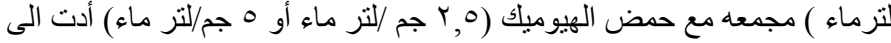

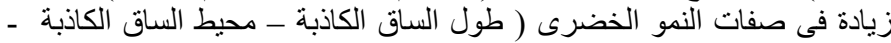

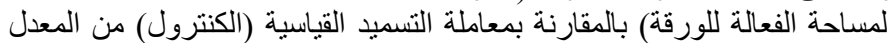

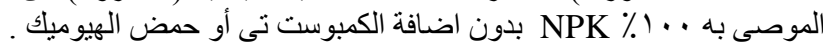

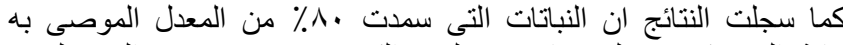

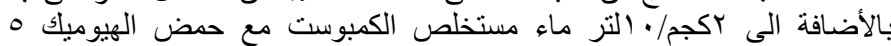

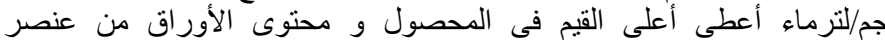

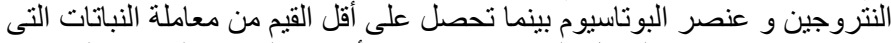

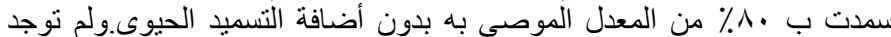

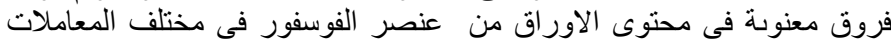
تحت الدر اسة.

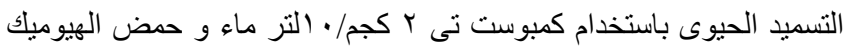

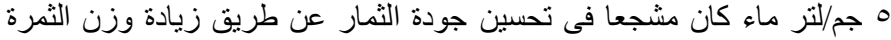

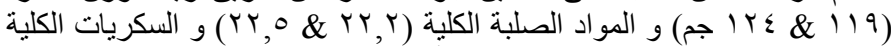

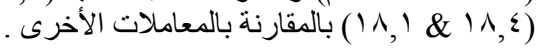

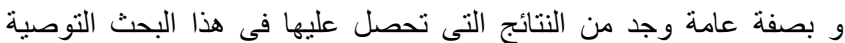

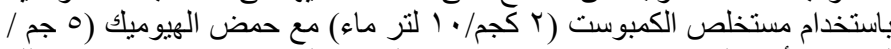

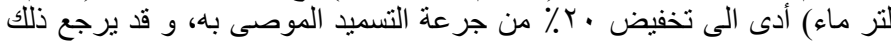

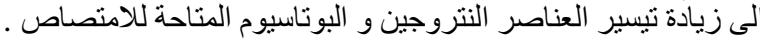

Egypt. J. Hort. Vol. 43, No. 2 (2016) 